\section{THE CALL OF THE ALPS.}

To the Editor of THE LANOwT.

SIR, - We observe that in your issue of Nov. 8th you quote official returns in disproof of the statement contained in our letter of October that "we are witnessing a veritable German exodus from Davos." Yet that statement is true. Your comparison of the numbers of visitors for two successive weeks affords no just criterion of a process lasting months. If for brevity's sake any two sets of figures are to be selected they should be the present returns and those for the same date last year, in order to eliminate the seasonal factor in fuctuation. There are now in Davos and neighbourhood in all 906 German visitors as against 2500 in November, 1918. Further, the decrease has been on the whole continuous, and that at a time of year when new arrivals were formerly numerous. It may be added in passing that the English have, on the contrary, just doubled their number.

We have reason to know that the general opinion of those interested differs widely from that expressed in your article in attaching great importance to this point, and we therefore ask you to find space for this reply to your criticism.

We are, Sir, yours faithfully,

\section{W. G. LOCKETT,}

British Vice-Consul.

Davos, Nov. 12th, 1919

ARNoLD H'. BILL, M.D.

** Dr. Bill has sent us a certified record of the number of visitors in the Davos Valley for the last 14 months, which, in the main, bears out his contention. Of the 2500 German visitors in November, 1919, 1000 or more were undergoing internment and did not, for some reason, figure in the usual return. The latest reported number of German visitors given as 867 includes 200 interned men, most of them patients in the Deutsches Kriegerhans at the mouth of the Dischmathal, as well as 140 or 150 patients in the Deutsche Heilstätte at Wolfgang. Dr. Bill adds: "As we now see him, the average German is a very mild edition of his former self, and the change in the atmosphere of Davos is even more noteworthy than the figures suggest."-ED. L.

\section{PORTRAITS OF ANDREAS VESALIUS.}

\section{To the Editor of THE LANOET.}

SIR,-Being engaged upon a work on the Iconography of Andreas Vesalius, I should be grateful if you will allow me to appeal to those of four readers with whom $I$ have not already corresponded on the subject and who own, or know of, any such portraits, painted or sculptured, to have the kindness to communicate with me. It is believed that certain of the portraits which at present are regarded as untraceable are to be found in institutions, in universities, medical schools, and the like, or in semi-public or private galleries. I may add that the book, which is to contain all the accessible portraits of the Father of Modern Anutomy, will be worthily produced under the authority, and with the support, of the "Annals of Medical History."

$$
\text { I am, Sir, yours faithfully, }
$$

$$
\text { M. H. Spimlmañ. }
$$

The Athenæum, Pall Mall, S.W., Nov. 26th, 1919

\section{MENTALLY DERANGED SOLDIERS IN PAUPER ASYLUMS. \\ To the Editor of THE LANCET.}

SIR,-The Parliamentary answer on this subject, reported on p. 950 of your issue of the $22 \mathrm{nd}$, is misleading. The fact that discharged soldiers who become insane are treated as private patients in asylums is, of course, all to the good, but, nevertheless, to gain admission to the asylum the unfortunate man has to be certified by the Poor-law medical officer, and goes in as a pauper. Transferring him to the private patient's side afterwards does not therefore meet the case.

Is it not possible to amend the law so that an insane pensioner can be treated as an insane serving soldier-i.e., be admitted (without certification) for observation, certification only being resorted to later if found to be necessary?

$$
\text { I am, Sir, yours faithfully, }
$$

Nov. 24th, 1919
THE LATE SIR T. LAUDER BRUNTON.

\author{
To the Editor of THE LANOET.
}

Sin,-In response to requests I propose to publish shortly a memoir of the late Sir T. Lauder Brunton. All profits from the sale of this book will be given to the sustentation fund of St. Bartholomew's Hospital. I should be very grateful for any communications from old friends of his, or for any letters of interest written by him. These would be carefully preserved and returned.

I am, Sir, yours faithfully,

7, Poole-road, Bournemouth. THOMAS BODLEY SCOTr.

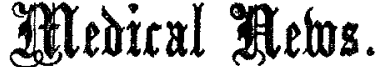

UNIVERSITY OF LONDON.-At a meeting of the Senate held on Nov. 19th Sir Cooper Perry was appointed principal officer. an appointment which has been in abeyance since 1915. A resolution was passed expressing appreciation of the Goldsmiths' Companv in presenting $£ 15,000$ National War Bonds to the London Hospital Medical College for the endowment of a University Chair of Bacteriology, and intimation was received of a bequest of about $£ 3000$ under the will of Mr. T. S. Hughes for the encouragement of original medical research in the University. It was also announced that the Graham Legacy Committee had made their first award of the gold medal to Dr. Charles Bolton, F.R.S., in recognition of original work in experimental pathology which be had conducted at the medical school of University College Hospital.

At examinations held recently the following candidates were successful :-

Third (M.B., B.S.) Examination for Medical Degrees.

Gerald Victor Wright Anderson, Univ. Coll. Hosp.; Owen Deane Brownfield, St. Thomas's Hosp.: Michael Waldo Boone Bulman, Lon on Ho+p.; Charles Hugh Colclough B rne, St. Thomas's Hosp.; Alix Jeanie Churchill, Lordon Sch. of Med. for Women and St. Gerrge's Hosp.; Simeon Moses Cohen, St. Brrt.'s Hosp; Rolf Creasy, Guy's Hosp.; Nora Anvie Crow, London Sch. of Med, tor Womer, Mary Day honours, distinguished in forensic medicine and midwifel y). St. Mary's Hosp.; Florence Marjory Hdwards, London Scb. of Med for Women: Reginald Stafiord Foss, St, Tuom*s's Hosp.; Pinkus Joreph Freilich and John Norman Glaister, Iniv. Coll. Hosp.: St. George Bernard Delisle Gray, Guy's H'sp. Hubert O'iver Gunewardene, King's Coll. Hosp.; Cyril Edward Harrison, Middlesex Hosp.; Henry Nevill Hornibrook, St. Bart.' Hosp.; Jack Joffe (honours, distinguished in pathnlogy and surgery), Guy's Hosp.: Shankar Ramehandra Joglekar, Univ. Coll. Hosp.; Rhys Trevor Jones (bonours, distinguished in medicine, forensic medicine, and surgery, Uuiversity medal), St. George's Hosp. : Samuel Walter Maslen Jones, Middlesex Hosp.; Vivinn Coll. Hosp.; Hyman Jacob Levy, Univ. Coll.. Cardiff, and St. Coll., Hosp.; Hyman Jacob Levy, Univ. Coll., Cardiff, and St. Guy Lyst er, Sr. Rart.'s Hosp.; Charles Dundas Maitland, St. Thomas's H'sp.; Framrez Nanabhov Moos, Univ. Coll. Hosp. and Grant Med C.,ll., Bombay; Marie Mathilda Alice Moralt, London Sch. of Med. for Women ; kidith Mary Ponsonby Morris, St. Mary's Hosp.; Manek Jamshedji Panthakp, King's Coll. H'ssp. ; John Ernest Perce. St. Bart.'s Hosp.: George Stuart Bain Philip, Charing Crose Hosp.; Frank Portas (bonours, distinguished in pathology), West minster Hosp.; Dornthy Priestley Priestley, Leeds Univ.; Mary Millicent Prior, St. Mary's Hosp. ; William Arthur Richards, Charing Cross Hosp.; John Francis Ryan. St Thomas's Hrsp.; Fimmanuel Prinski Scott, London Hosp.; Evelyn Dennis Scott, Guy's Hosp.; George Harold Sims, St. Thomus's Hosp.; Herbert William Southpate, Guy's Hosp.; Frances Minnie Spickett. London Seh. of Nen. for Women; Raymund Theron London Hosp.; Austin Darley Wall, St. Bart.'s Hosp.; Alfred Basi Keith Watkins (hunours, distinguished in medicine and surgery) London Hosp ; Crril James Berkeley Way, Midd esex Hosp. Whire-Couper, St. Bart.'s Hi.sp.; Alfred Williams Walker, BirWhire-Couper, St. Bart.'s He'sp.; ; Alfred Williams Walket,
minghsm Univ.; and Arthur Grabam Winter, London Hosp.

The following candidates have passed in one of the two groups of subjects :-

Group 1.-Dav1d William Jabez Andrews, Middlesex Hosp.; Mary Rushton Barkas. London Sch. of Med. for Women and St. Mary's Hosp.; William WAllace King Brown, St. Thomas's 'Hosp.; Eubert A ubr-; Lennnx Crichlow, King's Coll. Hosp.; William Edward Aubr ' Lennnx Crichlow, King's Coll. Hosp.; ' Winiam Edward Hosp.: Krnest Ivon Davies. Charing Cross Hosp.; Elizabeth Onwper Guves, Sheffield Univ, Harold Ellis and Thomas Leslie Ellis, St. George's Hosp.; Ro ald Kelson Ford, London Hosp.; Graydon George s Hosp.; Ro ald Kelson Ford, Land Pinkerton. London Scar of Med fror Women: 'Walter Ernest Karl Adolf Quitmann Univ. Coll, Hosp. John Augustus Waring Kobinson, King's Coll. Hosp.: and Beriah Melbourne Gwynne Thomas, Univ. Coll., Hosp.: and Beriah , Melbou

Group II. - Christian Frederick Heyers, St. Bart 's Hosp.; Ella Marianne Britten. St. George's Hosp.; Jacob Brodetsky, London Hosp.; John Ralph Dingley, Univ. Coll. A 'sp ; Abel Evans, Charing Cross Hosp ; Algernon Sanders Green, Univ. Coll. Hosp. Ceeil Edwart Eede Herington and Cbristopher Langton Hewer, St. Bart.'s Hosp. : Fric Clark Hinde. Guy's Hosp.; Oscar Hyam
Hyman, St. Thomas's Hosp.; George Ed win Kidman, Guy's Hosp.; 